AGRICULTURE AND BIOLOGY JOURNAL OF NORTH AMERICA

ISSN Print: 2151-7517, ISSN Online: 2151-7525, doi:10.5251/abjna.2011.2.6.1038.1041

(C) 2011, ScienceHuß, http://www.scihub.org/ABJNA

\title{
Lipid - lowering effects of bitter leaf (Vernonia amygdalina) in broiler chickens fed finishers' mash
}

\author{
${ }^{*}$ O.J. Owen ${ }^{1}$, A.O.Amakiri ${ }^{1}$ and T.A.Karibi-Botoye ${ }^{2}$ \\ ${ }^{1}$ Department of Animal Science, Rivers State University of Science \\ and Technology, P.M.B. 5080, Port Harcourt- Nigeria. \\ ${ }^{2}$ Department of Chemical Pathology, University of Port Harcourt \\ Teaching Hospital, Port Harcourt- Nigeria.
}

\begin{abstract}
The effect of graded levels of Vernonia amygdalina leaf meal (VALM) on serum lipid profile of broiler finisher chickens was studied. A total of 144 Marshal brooded broilers weighing 500 $610 \mathrm{~g}$ were randomly distributed into 4 groups of 36 birds each and assigned to $0 \%, 5 \%, 10 \%$ and $15 \%$ levels of VALM in a study that lasted for 28 days. The serum total cholesterol, triglycerol, High-density lipoprotein cholesterol (HDL-C) and Low-density lipoprotein cholesterol (LDL-C) levels were determined from blood samples at the end of the study. The serum concentration of cholesterol was significantly $(p<0.05)$ higher in the control when compared to the treated groups. The treatment with $V$. amygdalina at 5\%,10\% and $15 \%$ reduced the cholesterol concentration by $8.90, \quad 13.33$ and $26.67 \%$ respectively. Also there existed significant $(p<0.05)$ higher concentrations of triglycerol and low-density lipoprotein cholesterol (LDL-C) in the control group. The percentage reduction in triglycerol levels is $20.00,40.00$ and $46.66 \%$ respectively for treatments B (5\% VALM), C (10 VALM and D(15\% VALM). However, there was no significant $(p>0.05)$ in the concentration of high-density lipoprotein cholesterol (HDL-C) in both the control and the treated groups. While the inclusion of $V$.amygdalina reduced the levels of cholesterol and triglycerol at all levels to some extent, it further increased the levels of the HDL-C numerically at all levels of inclusion. These findings may be of clinical importance to individuals at risk of cardiovascular disease.
\end{abstract}

Keywords: Broiler chickens, cardiovascular disease,cholesterol, lipid profile, triglycerol

\section{INTRODUCTION}

Several factors such as lifestyle, a diet rich in cholesterol, age and hypertension, have been reported to cause heart failure (Schaefer et al., 1995), high levels of cholesterol, particularly LDL cholesterol, are mainly responsible for hypercholesterolemia (Krieger, 1998). It is known that hypercholesterolemia is risk factor for cardiovascular diseases (CVD) such as atherosclerosis and myocardial infection, which is a common cause of mortality and morbidity (Wald and Law 1995; Krieger, 1998). Recently, hypercholesterolemia has been associated with enhanced oxidative stress related to increase lipid peroxidation (Adaramoye et al., 2005). Increased generation of oxidized LDL is a major factor in the vascular damage associated with high cholesterol levels (Pritchard et al, 1995). Hence, the inhibition of oxidative stress under hypercholesterolemic conditions is considered to be an important therapeutic approach and efforts have been made to identify the antioxidative functions of various medicinal plants (Hu et al, 2006; Tomotake et al, 2006; Visavadiya and Narasimhacharya, 2007).

The use of plant extracts in managing various disorders is currently common place (Philip and Cephas, 1997). Many plant materials are also in current use as supplements (Block et al, 2007). Sometimes the aim is to lower the levels of some markers of disease states in order to improve health conditions (Ojiako and Nwanjo, 2009). An example may be found in the use of substances that lower the cholesterol level in the system.Many studies indicate that lowering the serum cholesterol may prevent, control and even reverse artherosclerosis and coronary heart disease. Low triacylglycerol and lowdensity lipoprotein cholesterol (LDL-C) levels or high density lipoprotein cholesterol (HDL-C) levels are desirable health outcomes known to have resulted from the use of some plant materials (Ojiako and Nwanjo, 2009). 
Agric. Biol. J. N. Am., 2011, 2(6): 1038-1041

Vernonia amygdalina (Compositae) is one of the edible vegetables in Nigeria and other parts of African sub region (Igbakin, 2009). As a vegetable it contains anti- nutrient substances like alkaloids, saponins and flavones that have medicinal properties (Germaniel and Akah, 1996; Nwafor and Akah, 2001). Other physiologically active compounds isolated from this plant include sequiterpene lactones - vernodaline and vernomyelin, asterol - 7, 24 (28) stigma astadiene - 3a-ol; toxic cardenolides and saponin (Igbakin, 2009). All these components have been proved to have physiological and metabolical effects on the body system. In Nigeria where the plant is found in abundance, it performs both medicinal and nutritive functions, it is used in the preparation of soup, prevention of malaria fever, elimination of worms, treatment of stomach upset, induction of fertility in barren women and treatment of diabetic mellitus (Kafaru, 1994) and hyperlipidemia (Adaramoye et al., 2008).

Given the traditional medicinal and domestic uses of $V$. amygdalina, there is need for elaborate physiological and biochemical aspects of the plant. The present communication describes the effects of this ethnic drug source on the serum lipid profile of broiler chickens

\section{MATERIALS AND METHODS}

The experiment was conducted at the poultry section of the Rivers State University of Science and Technology, Teaching and Research Farm in Port Harcourt, South - South of Nigeria. A total of 144 Marshal brooded broiler weighing $500-610 \mathrm{~g}$ were used in a study that lasted for 28 days. The birds were housed in a deep litter with wood shavings as litter material. Before the arrival of the birds, the pens were cleaned, washed and disinfected. The $V$. amygdalina leaves used were harvested from the cut branches of the shrub within the environment of Agip Estate; Port Harcourt Local Government Area in Rivers State, South-south of Nigeria. The leaves were spread and air-dried for 60 days and sun-dried for one additional day to ensure perfect drying, milled and packed in jute bags. The birds were divided into 4 groups of 36 birds each. Each treatment group was further subdivided into 3 replicates of 12 birds each in a Completely Randomized Design (CRD). The birds were assigned to $0 \%, 5 \%, 10 \%$ and $15 \%$ levels of VALM representing treatments $A, B, C$ and $D$ respectively. The experimental diets consisted of the following:

$\begin{array}{lll}\text { Treatment A } & \text { (0\% VALM) } & \begin{array}{l}19.82 \mathrm{CP} ; 2948.35 \mathrm{ME} \\ \mathrm{kcal} / \mathrm{kg}\end{array} \\ & & \begin{array}{l}19.50 \mathrm{CP} ; 2756.80 \mathrm{ME} \\ \mathrm{kcal} / \mathrm{kg}\end{array} \\ \text { Treatment B } & (5 \% \mathrm{VALM}) & \begin{array}{l}18.70 \mathrm{CP} ; 2678.30 \mathrm{ME} \\ \mathrm{kcal} / \mathrm{kg}\end{array} \\ \text { Treatment C } & (10 \% \mathrm{VALM}) & 17.90 \mathrm{CP} ; 2585.20 \mathrm{ME} \\ & & \mathrm{kcal} / \mathrm{kg}\end{array}$

Feed and water were offered ad libitum. Routine management practice and vaccinations were maintained while the study lasted. At the end of the study, 3 birds per treatment were randomly selected and bled by severing the jugular vein. Blood samples were collected without anticoagulant for blood chemistry evaluation at the Department of Chemical Pathology Laboratory of University of Port Harcourt Teaching Hospital. The blood parameters determined includes Total cholesterol, triglycerol, High -density lipoprotein (HDL-C) and Low-density lipoprotein (LDL-C) and all the data collected were subjected to Analysis of Variance (ANOVA) according to Steel and Torrie (1980) and Means were partitioned where necessary using Duncans New Multiple Range Test (DNMRT) as outlined by Obi (1990).

\section{RESULTS AND DISCUSSION}

Table 1 shows the effect of graded levels of Vernonia amygdalina leaf meal on the lipid profile of broiler chickens. The serum concentration of cholesterol was significantly $(p<0.05)$ higher in the control when compared to the treated groups. The treatment with V. amygdalina at 5\%,10\% and $15 \%$ reduced the cholesterol concentration by $8.90,13.33$ and $26.67 \%$ respectively. Also there existed significant $(p<0.05)$ higher concentrations of triglycerol and low-density lipoprotein cholesterol (LDL-C) in the control group. The percentage reduction in triglycerol levels is $20.00,40.00$ and $46.66 \%$ respectively for treatments B (5\% VALM), C (10 VALM and D(15\% VALM). However, there was no significant $(p>0.05)$ in the concentration of high-density lipoprotein cholesterol (HDL-C) in both the control and the treated groups. While the inclusion of $V$.amygdalina reduced the levels of cholesterol and triglycerol at all levels to some extent, it further increased the levels of the $\mathrm{HDL}-\mathrm{C}$ numerically at all levels of inclusion.

Lipid profile (which involves levels of total cholesterol, HDL, LDL and triglycerol) serve as diagnostic indices in conditions such as chronic obstructive jaundice, hepatitis, coronary heart disease and atherosclerosis. Hyperlipidaemia is one of the risk factors for coronary heart disease while cholesterol is the major lipid 
constituent of atherosclerotic plaque (Ekpo et al., 2007). The use of $V$. amygdalina significantly lowered the cholesterol and triglycerol profiles of the broiler chickens indicating that the use of the plant will not likely contribute to any disease associated with hyperlipidaemia. The elevated levels of triglycerol and cholesterol obtained in the broiler chickens not administered $V$. amygdalina leaf meal are in line with the findings of Adaramonye et al., (2005); Yokozawa et al (2006); Ekpo et al., (2007) and Adaramonye et al (2008).

The results suggest that VALM reduced the triglyceride biosynthesis and favour the re-distribution of cholesterol among the lipoprotein molecules. This observation is consistent with the findings of Ojiako and Nwanjo (2009) in which $V$. amygdalina significantly attenuated the hepatic triglyceride and LDL cholesterol levels of streptozotocin diabetic rats.

In the present study the use of $V$. amygdalina leaf meal in all the levels numerically increased the HDLCholesterol. One of the crucial risk factors for cardiovascular disease (CVD) includes a low level HDL-Cholesterol. The association between a low level of HDL-cholesterol and an increased risk of CVD has been well established through epidemiological and clinical studies (Assmann and Gotto, 2004). It is known that low level of HDLCholesterol plays a direct role in the atherogenic process; therapeutic intervention to raise $\mathrm{HDL}$ cholesterol together with other risk factors is widely encouraged. From this study, incorporation of $V$. amygdalina into finisher broiler diets numerically elevated HDL-cholesterol, indicating its promising protective role against CVD. The protective roles of HDL cholesterol from CVD have been suggested to occur in various ways (Nofer et al, 2002). HDL exerts part of its anti-atherogenic effect by counteracting LDL oxidation and recent studies also showed that
HDL promotes the reverse cholesterol transport pathway, by inducing an efflux of excess accumulated cellular cholesterol and prevents the generation of an oxidatively modified LDL (Yokozawa et al, 2006). From our study, V. amygdalina may probably have played the anti-atherogenic role through the elevation of HDL cholesterol. LDLcholesterol is another primary target of CVD riskreduction therapy (Kwiterovich, 1997). In this study, the incorporation of $V$. amygdalina at all levels significantly lowered LDL-cholesterol levels. Excess LDL-cholesterol can be deposited in the blood vessel walls and becomes a major component of atherosclerotic plaque lesions (Adaramoye et al; 2008).

Therefore, plasma LDL-cholesterol level may be used in monitoring the treatment of patients with elevated blood cholesterol levels (Adaramoye et al; 2008). In our findings $V$. amygdalina elicited beneficial effects by lowering the levels of cholesterol including the LDL of the broiler finisher chickens.

Evidence from this study confirms the lipid-lowering effects of $V$. amygdalina. The medicinal properties of this plant have been attributed to the biochemicals resident in the plant. It is clear from this study that this plant owe its lipid-lowering properties to its selective chemical composition, and that proper knowledge of the proximate composition, phytochemical and micro-nutrient composition is fundamental to understanding the mode/mechanism of anti-atherogenic action of this plant. Further studies are therefore warranted to identify the exact component in $V$. amygdalina responsible for the observed effect and such component may be a candidate for use as a prophylactic agent against hypercholesterolemia.

Table 1: The effect of Vernonia amygdalina on the lipid profile of broiler chickens.

Treatments

\begin{tabular}{|c|c|c|c|c|}
\hline & $\begin{array}{c}\text { A } \\
\text { VÅ } \\
\text { VALM) }\end{array}$ & $\begin{array}{c}\text { B } \\
\text { (5\% } \\
\text { VALM) }\end{array}$ & $\begin{array}{c}\text { C } \\
\text { (10\% } \\
\text { VALM) }\end{array}$ & $\begin{array}{c}\text { D } \\
\text { (15\% } \\
\text { VALM) }\end{array}$ \\
\hline \multicolumn{5}{|l|}{ Parameters } \\
\hline Cholesterol $\mathrm{mmol} / \mathrm{l} \pm \mathrm{SEM}$ & $4.50^{\mathrm{a}} \pm 0.30$ & $4.10^{\mathrm{a}} \pm 0.35$ & $3.90^{b} \pm 0.20$ & $3.30^{b} \pm 0.30$ \\
\hline Cholesterol reduction (\%) & 0 & 8.90 & 13.33 & 26.67 \\
\hline Triglycerol $\mathrm{mmol} / \mathrm{l} \pm \mathrm{SEM}$ & $1.50^{\mathrm{a}} \pm 0.20$ & $1.20^{\mathrm{a}} \pm 0.30$ & $0.90^{b} \pm 0.25$ & $0.80^{b} \pm 0.30$ \\
\hline Triglycerol reduction (\%) & 0 & 20.00 & 40.00 & 46.66 \\
\hline $\mathrm{HDL} \mathrm{mmol} / \mathrm{l} \pm \mathrm{SEM}$ & 1.00 & 1.02 & 1.10 & 1.20 \\
\hline $\mathrm{LDL} \mathrm{mmol} / \mathrm{l} \pm \mathrm{SEM}$ & $3.60^{\mathrm{a}} \pm 0.35$ & $3.50^{\mathrm{a}} \pm 0.30$ & $340^{b} \pm 0.25$ & $3.40^{b} \pm 0.15$ \\
\hline
\end{tabular}

Within rows, means \pm SEM with different superscript differs significantly at $p<0.05$. SEM: Standard Error of Means 


\section{REFERENCES}

Adaramonye, O.A.; Nwaneri, V.O.; Anyanwu, K.C. (2005). Possible anti-atherogenic effect of kolaviron (Garcinia kola seed extract) in hypercholesterolemic rats. Clin. Exp Pharmacol Physiol., 32: 40 - 46.

Adaramoye, O.A.; Akintayo, O.; Achem J. and Fafunso, M.A. (2008). Lipid-lowering effects of methanolic extract of vernonia amygdalina in rats fed high cholesterol diet. http://www.tribune.com.ng/27062008/thr/htt2.html

Assman, G. and Gotto, A.M. Jnr. (2004). HDL - cholesterol and protective factors in atherosclerosis. Circulation. 109: III 8 - III 14.

Block, G.; Jensen, C.D.; Norkus, E.P.; Dalvi, T.B.; Wong, L.G.; McManus, J.F. and Hudes, M.L. (2007). Usage patterns, health and nutritional status of long term dietary supplement users: a cross-sectional study. Nutr. Journal 6:30.

Ekpo, A.; Eseyin, A.O.; Ikpeme, A.O. and Edoho, E.J. (2007). Some studies on some biochemical effects of Vernonia amygdalina amygdalina in rats. Asian J. of Biochem. 2 (3): 193-197.

Germaniel, K.S. and Akah, P.A. (1996). Analysis of gastrointestinal relaxing effect of the stem extract of Gongronema latifolum. Phytomedicine, 2 (4): 293 296

Hu, S.H.; Liang, Z.C.; Chia, Y.C. (2006). Antihyperlipidemic and antioxidant effects of extracts from Plenrotus citrinopileatus. J. Agric. Food Chem.. 22: 2103 - 2110.

Igbakin, A.P. (2009). Comparative studies on the hypoglycaemic, hypoproteinaemic hypocholesterolaemic and hypolipidaemic properties of ethanolic and normal saline extracts of the root of $\mathrm{V}$. amygdalina in diabetic rats. Advances in Environmental Biology, 3 (1): 33 - 38.

Kafaru, E. (1994). Immense help for natures workshop public. Elkaf Health services Ltd, Benin - city, Nigeria, $54-58$.

Krieger, M. (1998). The "best" of cholesterols, the "worst" of cholesterols: a tale of two receptors. Proc. Natl. Acad. Sci. USA., 95: 4077 - 4080.

Kwiterorich P.O. Jnr. (1997). The effect of dietary fat, antioxidants, and pro-oxidants on blood lipids, lipoproteins, and atherosclerosis. Journal Am. Diet Assoc., 97:S31 - 41.
Nofer, J.R.; Kehrel, B.; Fobver, M. (2002). HDL and arteriosclerosis: beyond reverse cholesterol transport. Atherosclerosis, 161: 1 - 16.

Nwafor, S.U.P.A and Akah, C.O. (2001). Potentials of plant products as anti-cancer J. of Natural Remedies 1:75 88.

Obi, I.U. (1990). Statistical methods of detecting differences between treatment means. $2^{\text {nd }}$ ed. Snap Press, Enugu - Nigeria.

Ojiako, O.A. and Nwanjo, H.U. (2009) Biochemical studies of the effects of the aqueous extract of Nigerian garlic on lipid profile and artherogenic risk predictor indices. Australian Journal Basic and Applied Sciences, 3 (3): $2861-2865$

Philip, B. and cephas, T.B. (1997). The effect of plant extracts on plasma glucose levels in rats. Journal of Clinical Chemistry, 10 (5): 167 - 169.

Pritchard, K.A. Jrn.; Groscek, L.; Smalley, D.M. (1995). Native low-density lipoprotein increases endothelia cell nutric oxide synthase generation of superoxide amion Circ. Res.; 77:510 - 518.

Schaefer, E.J.; Lichtenstein, A.H.; Lamon-Fava, S. (1995). Lipoproteins, nutrition, aging and atherosclerosis. Am. J. Clin. Nutri., 61: 726S - 740S.

Steel, R.G.D and J.H. Torrie (1980). Principle and procedures ofstatistics. $2^{\text {nd }}$ ed. MacGraw - Hill. Singapore.

Tomotake, H.; Yamanoto, N.; Yanaka, N. (2006). High protein buckwheat flour suppresses hypercholesterolemia in rats and gall stone formation in mice by hyperchotesterolemic diet and body fat in rats because of its low protein digestibility. Nutr.; 22: $166-173$

Visavadiya, N.P. and Narasimhacharya, A.V. (2007). Ameliorative effect of Chorophytum borivilianum root on lipid metabolism in hyperlipaemic rats. Clin. Exp. Pharmacol. Physiol., 34: $244-249$.

Wald, N.J. and Law, M.R. (1995). Cholestrol and ischemic heart disease. Atheroscherosis. 118: $1-5$.

Yokozawa, T.; Cho, E.J.; Sasaki, S. (2006). The protective role of Chinese prescription kangen-karyu extract on diet - induced hypercholesterolemia in rats. Boil. Pharm Bull. 29:760 - 765. 